\title{
Bartholomaeus Anglicus on Gold
}

\section{THE MODERN VIEWS OF A MEDIAEVAL ENCYCLOPAEDIST}

\section{B. Hunt}

Johnson Matthey \& Co Limited, London

\begin{abstract}
6 And when a plate of golde shall be bonded with a plate off silver, or joyned thereto, it needeth to beware of three things, of dust, of winde, and of moysture, for if any hereof come betweene golde and silver, they may not be joyned together the one with the other; and therrefore it needeth to bond these two mettals together in a full cleane pllace and quiet.9
\end{abstract}

These words might very well describe the precautions necessary to the production of the sophisticated types of gold-faced or gold-inlaid contact materials nowadays so much in use in the electronics industry, a technique requiring not only careful control of the bonding process and subsequent rolling but also an exceptional degree of cleanliness, often achieved only by conducting operations in a specially designed area that is air-conditioned and entirely free from contamination.

In fact, they were written, in Latin, well over 700 years ago by a Franciscan friar, and the version given here is only very slightly modernised from the English translation made in the year 1398 .

They come from a massive encyclopaedia, $D e$ Proprietatibus Rerum-_"The Properties of Things"compiled around the year 1250 by Bartholomew the Englishman, or Bartholomaeus Anglicus as he was known to his contemporaries, to provide a compendium of knowledge, largely for the use of the preaching friars; the chapter on gold includes some further perceptive comments on this metal which we shall come to later.

The author of this work, born in Suffolk in about 1205 , went up to Oxford at an early age to study under the famous Robert Grosseteste, the first chancellor of the newly founded University and afterwards Bishop of Lincoln. To Grosseteste, who greatly influenced the young Bartholomaeus, we owe a great deal, in that he was the first to interrelate the old methods of logical argument, as used by Aristotle, to scientific experiment, thus really taking the first steps towards the creation of modern science as well as founding a distinguished school of scientific thought.

Grosseteste also had an affection for the Franciscans, who had arrived in Oxford in 1224, two years before the death of St Francis, and he not only lectured to them but provided a house for their studies. At this time there was also a strong link and an interchange of both men and ideas between the new Universities of Oxford and of Paris, and in 1219 Bartholomaeus himself moved to Paris to take up a teaching post, and a little later, no doubt again influenced by Grosseteste, joined the Franciscans. Here the remained until, in 1230, he was called to become lecturer to the newly founded Franciscan "studium" at Magdeburg in Saxony.

The material for the great encyclopaedia was probablly planned during his days at Oxford, assembled mainaly during his period in Paris, and the work was completed in Magdeburg. Its date can be established fairly closely as around 1250, and it rapidly: became a standard work, the manuscript being copied widely and used as an authority for very many years, in fact for centuries.

Before considering the nature of the encyclopaedia, and im particular its section on gold, it is necessary to appreciate the state of scientific and technical knowledige in the early part of the thirteenth century. Europe at this period knew little of medicine,

\footnotetext{
Many copies of the De Proprietatibus Rerum of Bartholomaens stiill survive. This page is from an illuminated manuseriph dating from 1323 and now in the Vatican Librawy. Ih shows the major part of Book XVI, Chapter 4, "De Auro". The passage quoted above in mediaeval English can be identified in the Latin original, with some abbreviations, heginning fourteen lines up from the bottom of the lieft hand column: $q(u a) n(d o)$ aut(em) lamina brachea axrea cum argentea s(u)bducta debet malleando incexperary̆ nece(ess)e e(st) actib(us) maxime precau(er)i sed apulu(er)e uento et hu(m)ore quia si aliq(uid) horman int(er) aurum et argentum se $p$ (er)miscuerit, nequarg(uam) unum cum altero se tenebit. Et ideo oportet ut in loco ualde mundo et quieto hec duo metalla ad invieemu uniantur
} 


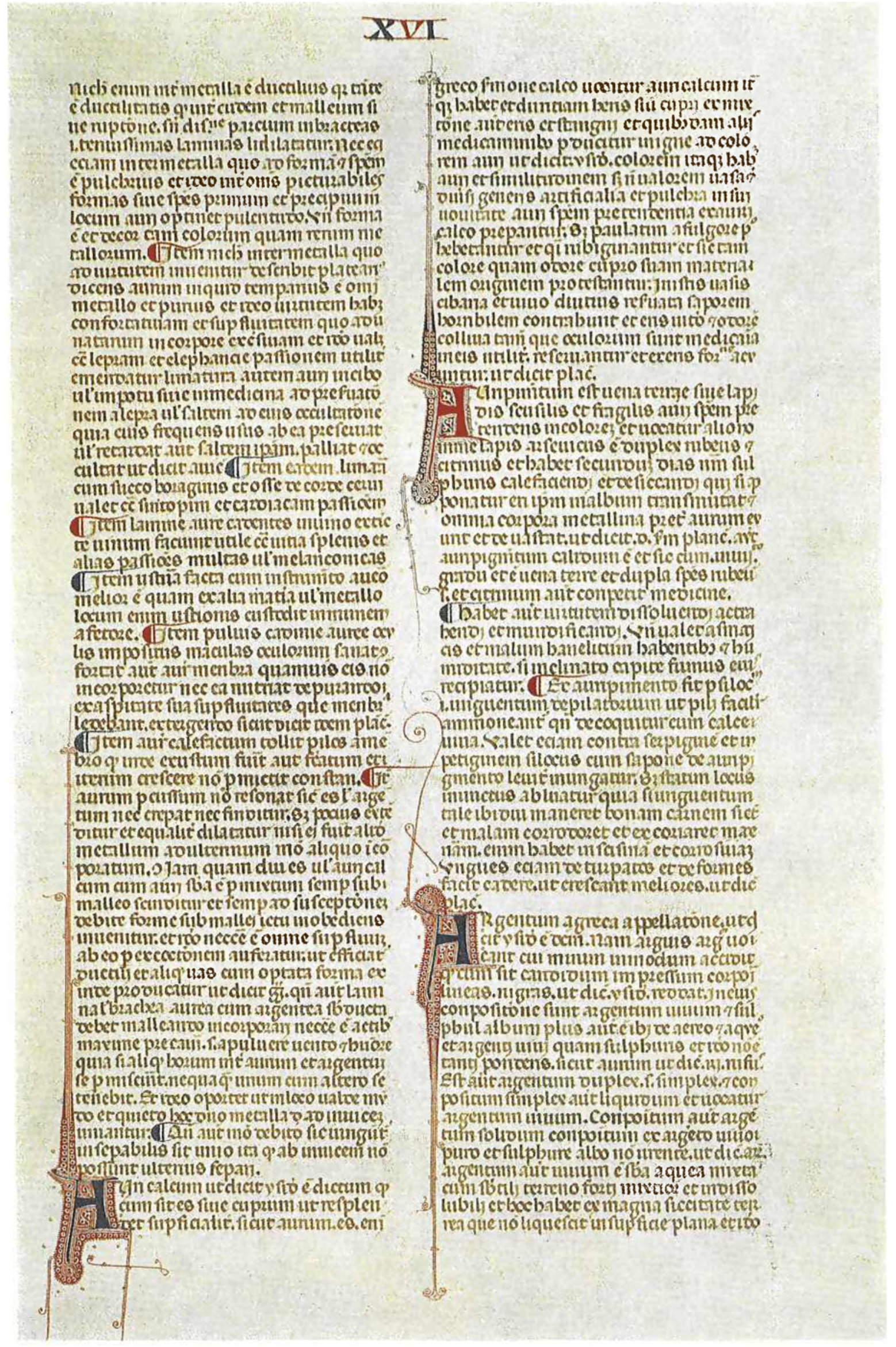


chemistry, physics, mathematics, or astronomy, the only works available being a few collections of practical recipes for such processes as dyeing, the colouring of metals and the making of pigments which had come down via the libraries of Constantinople from Greek sources in Alexandria. By the second half of the twelfth century the attention of learned men in Europe had been drawn to the large number of Greek and Arabic manuscripts that were becoming available to them, greatly superior to their own sources in the knowledge of nature and of practical skills.

\section{The Transmission of Greek Learning to Europe}

Greek science returned to Europe through the Muslim world. The great conquests of the seventh and eighth centuries-ranging from Persia and Mesopotamia to Spain-had given the Arabs access to a wealth of Greek learning among the civilised peoples they had overrun, and the manuscripts they found were eagerly translated in the ninth century into Arabic in the schools established in Baghdad, Damascus and Cairo, and in some of the cities of Spain. This store of knowledge, supplemented by the work of Arab scientists, was then transmitted to mediaeval scholars in Europe in a great wave of travel and translation. Spain was the principal legatee of Arabic learning, and by the twelfth century, when Europe had become more settled and established, a number of distinguished translators, including Adelard of Bath, Gerard of Cremona and Robert of Chester (who completed the translation of the first book on alchemy to be given to the west in 1144) were hard at work in Toledo, Segovia, Seville, Barcelona, and other Spanish centres. Another major source of translations was the famous court of Friedrich II"Stupor Mundi"-in Norman Sicily, where a band of scholars-Christian, Jewish and Muslim working together-was maintained and encouraged by the Emperor, while to a lesser extent Greek texts were also received directly into Europe and put into Latin.

Thus by somewhere around 1200 a great body of early scientific and technical knowledge had been absorbed into Western Europe, and-although scholarly works on this subject tend to overlook ita great interest was being taken in some of the more practical scientific problems; in fact one of the motives for the great interest in Arabic learning was the practical knowledge to be gained.

\section{The Age of the Encyclopaedia}

This stimulation of the desire for learning began to make it impossible for students to acquire at first hand a knowledge of all that was becoming available, while the collection of a substantial library of manuscripts was also a near impossibility. So began the period of the encyclopaedia, and Bartholomew was not alone in seeking to provide a more convenient means of instruction and education, although it was to the Franciscans that fell the main burden of spreading both secular and religious knowledge. It was they, with a few others from the rival Dominican order, who undertook much of the invaluable work of selecting and arranging the new material for general use by both the laity and the clergy.

Alexander Nequam, for instance, an Englishman from St Albans, and a foster-brother of Richard I, had lectured in Paris but had returned to England by 1182 and there compiled his Liber de Naturis Rerum "On the Nature of Things"-a mass of scattered information of a scientific nature and the forerunner of Bartholomew's work-in about 1200.

Alexander of Hales, another Englishman from Gloucestershire and a Franciscan, also working in Paris, produced his Summa in about 1230, a work described scathingly by Roger Bacon as "weighing about as much as one horse could carry". Albertus Magnus, a Dominican, was yet another encyclopaedist, as was his pupil Thomas Aquinas. Roger Bacon, also an Englishman and a Franciscan who was a student under Grosseteste and who went on from Oxford to Paris, compiled his Opus Majus in 1268. Another contemporary of Bartholomew's, the French Dominican Vincent of Beauvais, who was librarian and chaplain to Louis IX, was the author of a vast work, also written in about 1250 , in eighty books and nearly 10,000 chapters, the Speculum Majus, which he claimed "included whatever has been made or done or said in the visible and invisible world from the beginning until the end". It has been described as "a popular patchwork", but like Bartholomew's work although much larger and less methodical, it was read and quoted for several centuries, although it was not made accessible in English.

All these works were written in mediaeval Latin, as of course was the great encyclopaedia of Bartholomaeus Anglicus, the most popular work of the kind in the thirteenth century.

Although he occasionally gave his own commentaries, Bartholomeaus was not an original writer, and took care to quote all his authorities, including contemporaries such as Robert Grosseteste and Albertus Magnus. The list of his authorities given at the beginning runs to 105 names, including $\mathrm{St}$ Augustine, St Gregory, Galen, Hippocrates, Avicenna, Pliny, Virgil, Cicero, Plato, Dioscorides, Ptolemy, Herodotus, Isidore of Seville, and Bede. The style of writing is clear, concise and methodical, as one would expect from a pupil of Grosseteste, while the wealth of information displays not only a very wide reading on the author's part but an originality of treatment and a breadth of view. A great number of manu- 
The translation of De Proprietatibus Rerum made by John Trevisa at Berkeley Castle, finished in 1398, is one of the earliest examples of English prose. It was printed in 1495 by Wynkyn de Worde and the concluding passage from the chapter on gold is reproduced here. To relate this to the quotation given at the head of this article and to the manuscript version in Latin a little explanation is perhaps necessary. The verb to meddle at this time had the meaning of mixing, mingling or blending and has been interpreted in the present context as bonding, although the Latin malleando could simply mean hammered. Trevisa renders the Latine pulvere as powder, but this would be better translated as dust. The term "wind" is still in use by older workmen to describe the occasional blister of air that causes rejections in the production of gold-clad silver or other metals

script copies were made and circulated among the universities and monasteries, and something over 100 copies still survive in the great libraries of the world. Roger Bacon referred to it in 1267 as "a well known work of reference", and by 1286 a copy was available on loan to students in the Sorbonne. Copies were sent to England as well as to other European countries, and one surviving manuscript in the Bodleian Library at Oxford dates from 1296.

\section{The Translations of Bartholomaeus}

The first translation into a modern language was made in 1372 for Charles V of France, a great collector of books and the founder of the Royal Library at the Louvre, by his chaplain Jean Corbichon. In 1398 an English translation was made by John Trevisa, a Cornishman, an Oxford graduate and chaplain to Sir Thomas Berkeley of Berkeley Castle in Gloucestershire. Trevisa, at a time when Latin and Norman French were only just disappearing as the common tongues of England, played a great part in the early development of English prose (English was first used in the law courts only in 1362 and a year later for the first time in the opening of Parliament). His translation-contemporary with Chaucer's Canterbury Tales-was begun shortly after he had completed the translation of the Polychronicon, the then standard work on general history written by the Chester monk Ranulph Higden, and was finished on 6th February, 1398, as the following rather delightful last paragraph shows. One can almost hear the sigh of relief mixed with pleasure at the completion of the great task he had undertaken:
Ello golo (mptey townytb not as bras ontb e Cpluet:noz brekety ne deuptb but itecthith eupro abrode:but pf ocber aton ge metall be meoleo thejw in fome wp le. for as longe as bias or lators is mes olvo with ś fubitaitce of golo:it cleueth alwap bnoer bo bamour e is inobeopene to talse oue thape by betpng of $\dot{p}$ bamo ui/ Ano thetfore it neopth of all Cupflui. te be puttawape:e the goloe clentpo bp. melepng e made pure. $p$ it mape be abte to be thape wf a bamout to make the: of fome veflell woth couenable thape as

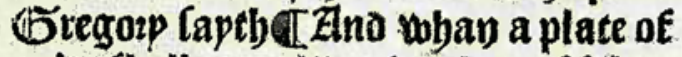
goloe thalle meolio we a plate of tplues. of Jopneo thento:it neoeth to bewar na mely of thre thpnges. of poware/of wph de. ef of mopture. ffor yf onp besot com betwene golde e fpluer thep may not be Jopreo togyo: ne the one wotb $\hat{w}$ otber. Zno thet fore it neoeth to meole thpie. in metals togpi iv a full cleneplace e quie te. e whan thei be Jopnes in oue maner: po onyrtg is intepable:to p thep map not afterwaroe be oeparted aconore.

\footnotetext{
Endless grace, blysse, thankyngs and praysings unto our lorde god Omnipotent be gyven, by whose ayde and helpe this translation was ended at Berkeley the vi daye of Feuerer, the year of our lorde MCCClxxxxviii, the yere of the reygn of King Rycharde the seconde after the Conqueste of England xxii. The year of my lordes age, Syre Thomas lorde of Berkeley, that made me to make this Translation xlvii.
}

In the fifteenth century translations were made into German, Italian, Spanish, Dutch, and even into the Provençal language.

Trevisa's English translation circulated in manuscript form, and a few copies survive, but in 1495 a printed version appeared. This was produced at Westminster by Wynkyn de Worde, the assistant and successor to William Caxton, and is a most beautifully produced book.

Printed versions now began to appear in Latin, French and German, while a further English edition was published in London by Thomas Berthelet in 1535.

An extract from the Wynkyn de Worde edition of 'Trevisa's translation, the last paragraphs from the book on gold, is illustrated here, but for the modern 


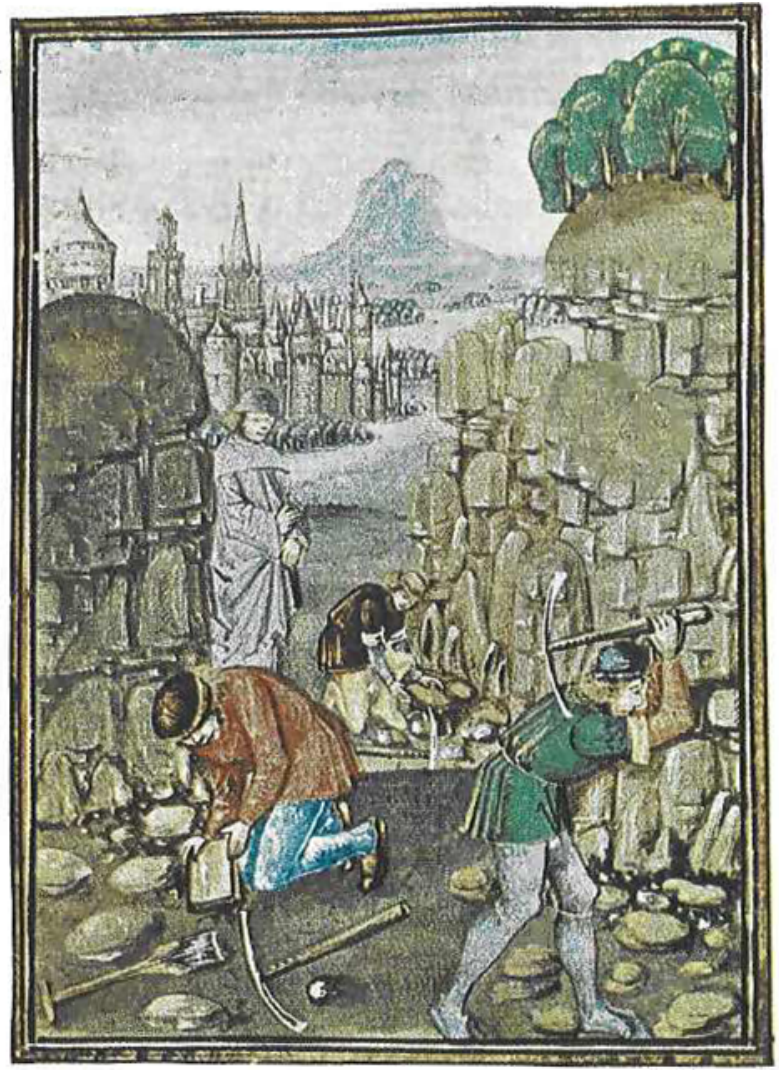

reader it is preferable to draw upon a later edition, published during the reign of Queen Elizabeth $I$.

This was the work of Dr Stephen Batman, a Cambridge man who had the reputation of being "a learned man and an excellent preacher", and was printed in London in 1582 under the title:

\section{BATMAN VPPON BARTHOLOME}

\section{His Booke De Proprietatibus Rerum,}

Newly corrected, enlarged and amended: with such Additions as are requisite, unto every severall Booke.

Batman made use of Trevisa's translation and although he made his own additions, particularly on theological subjects, he did not interfere with the scientific matter. It was this edition of Bartholomaeus that was well known to Shakespeare, who drew upon it quite extensively in his allusions to the stars and to plants and animals. By now over 300 years old, Bartholomew's massive work was still very much alive and sought after.

The encyclopaedia was organised in nineteen books, each of numerous chapters, and covered virtually everything that was known or imagined, from God and the angels to fire, water, air, earth and all its contents-animal, vegetable and mineral-as well as the best methods of bringing up children.

It is Book XVI which is of interest to us: this carries the heading:
Among the many manuscript yersions of Bartholomaeus Anglicus was a beautifully illustrated and bound copy written in French by Jean du Ries in Bruges in 1482 for presentation to King Edward IV of England and now in the British Museum. This miniature heads the chapter on gold and is intended to illustrate mining operations

The sixteenth book declareth and sheweth the nature and properties of alle stones and the generatyon of all mannre metalles.

Chapter 4, "Of Golde", opens with some general statements:

Golde is called Aurum, and hath that name of Aura, still whether, as Isidore saith. For it shineth with bright beams and is of best colour.

After some alchemical references of little value today, and a number of quotations from Aristotle, the chapter goes on:

Then among metals nothing is more sad in substance, or more better compact, than golde; and therefore though it bee put in fire, it wasteth not by smoaking or vapours, neither lesseth the waight, and so it is not wasted in fire; but if it be melted with strong heate, then if any filth be therein, it is cleaned thereof, and that maketh the golde more pure and shining. No metall stretcheth more with hammer worke, than golde, for it stretcheth so, that betweene the anfield and the hammer without breaking and renting into pieces, it stretcheth to leaf golde.

The next section extols the virtues of gold in a medicinal sense, even for the treatment of leprosy and "cardiacle passion", "evils of the spleen and other evils", while there is a foreshadowing of the use of gold in treating rheumatoid diseases- "golde comforteth lymmes ... it doth away with the sharpness of superfluites that growe in members and cleanseth them in that wise, as Plato saith". 
Although it is nearly 300 years later than the time of Bartholomaeus, this illustration from Vanoccio Biringuccio's Pirotechnia, published in Venice in 1540, shows the method of bonding gold to silver practised in the middle ages

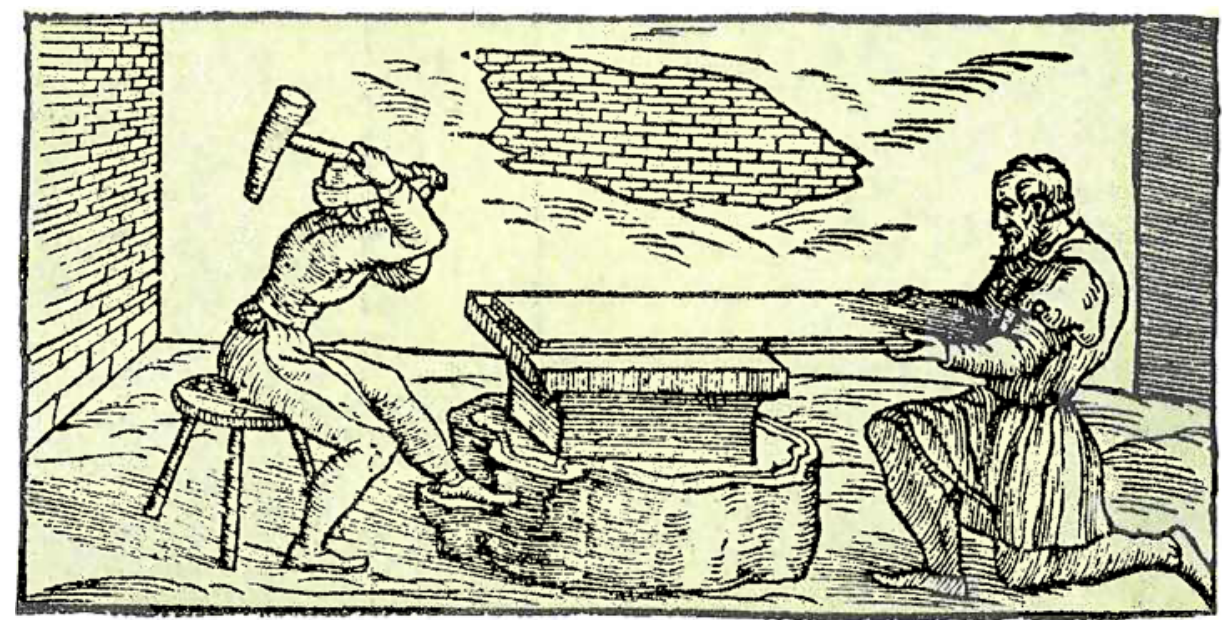

A later passage has this to say about the fabrication of gold:

Also gold smitten soundeth not as brasse doth and silver, nor cracketh nor cleaveth, but stretcheth even abroad, except other strong metall be medled therewith in some wise. For as long as brasse or Latton is medled with the substance of gold it cleaveth alway under the hammer and is inobedient to take out shape by beating of the hammer: and therefore it needeth that all superfluitie be put awaye, and the golde cleansed by melting and made pure, that it may be able to be shapen with a hammer, to make thereof some vessell with covenable shape as Gregory sayth.

For the latter part of this paragraph Bartholomaeus was perhaps a little unfortunate in his choice of authority, St Gregory of Nazianzus, one of the early Fathers of the Church and Bishop of Constantinople around the year 380. Gregory was a prolific writer and orator, with a highly developed sense of imagery, and his comments on the effects of brass ("auricalco", which was more likely to be a tin-copper bronze at this time) were of more metaphorical than metallurgical significance, to emphasise the importance of purifying the soul!

The final paragraph, which includes the passage quoted at the head of this article, runs as follows:

And when a plate of golde shall be medled with a plate of silver, or joyned thereto, it needeth to beware namely of three things, of powder, of winde, and of moysture: for if any hereof come betweene golde and silver, they may not be joyned together, the one with the other: and therefore it needeth to meddle these two mettals together, in a full cleane place and quiet, and when they be joyned in due maner, the joyning is inseparable, so that they may not afterward be departed asunder.

Now at the end of this last passage Bartholomaeus does not quote any authority; it must therefore have been the product of his own knowledge. Bartholomaeus was certainly a man of keen observation, and he had travelled in Flanders and Holland and commented on their industries and agriculture before undertaking his journey to Magdeburg. Where then did he acquire this remarkable understanding of the bonding of gold to another metal? The most likely source was among the goldsmiths working on the Pont au Change and the Quai des Orfevres in Paris; in 1292 no less than 116 goldsmiths and jewellers were recorded in this area.

The bonding of gold to silver or to other metals, although a procedure nowadays well established and relied upon in modern industry, was obviously open to fraudulent practices. Ordinances were made in Paris in the thirteenth century, not long after Bartholomaeus completed his encyclopedia, forbidding the cladding of silver with gold but were apparently repeatedly ignored by the goldsmiths, while in London in 1238, in the reign of Henry III, it was ordained that, in consequence of the frauds that had been practised by the goldsmiths it had become necessary to prescribe some regulations for their trade; these included an item "that no one shall put gold on brass or copper".

The bonding of a thin layer of gold to a backing material such as copper, bronze or silver is of course nowadays accepted as it has the obvious advantage of providing the desirable properties of gold where they are needed with an economy in cost. The later development, during the eighteenth century, of the bonding of carat gold alloys to base metals led in fact to the large-scale production of the "rolled gold" used so widely in costume jewellery, watch cases, fountain pens and spectacle frames. This perhaps Bartholomaeus could have foreseen; what he certainly could not have imagined was the advent of gold-clad electrical contact materials for the electronic and telecommunications industry, produced "in a full cleane place and quiet". 